\title{
中国における住宅の暖房負荷の地域特性 REGIONAL CHARACTERISTICS OF HEATING LOADS FOR APARTMENT HOUSES IN CHINA
}

\author{
張 晴 原*, 浅野賢二**, 林 徹夫***, 今井 計**** \\ Qingyuan ZHANG, Kenji. ASANO, Tetsuo HAYASHI \\ and Hajime IMAI
}

\begin{abstract}
In this study, the Typical Weather Year data for the simulations of buildings were developed following the previous study. Using these data, the annual heating loads of 46 Chinese cities were calculated. A regression equation was made to estimate the annual heating loads using the simulation results. The regional characteristics of the annual heating loads were made clear. The main conclusions from this study are as follows: $a$. The number of cities whose Typical Weather Data were developed were increased to 46 from 25; b. A regression equation was developed to estimate the seasonal heating loads, the results from which agree with the simulation very well; c. A map with isometric lines of heating loads was developed; and d. The annual heating loads are decided not only by the latitude but also by the altitude of the location.
\end{abstract}

Keywords: annual heating loads, regional characteristics, simulations, regression equation 年間暖房負荷, 地域特性, シミュレーション, 回帰式

1. はじめに

近年, 急速な経済成長に伴って, 中国における民生用エネルギーの 消費量が著しく增大している。特に都市部では, 空調設備の普及が, 民 生用エネルギー消費の顕著な伸びの主因になっている。そのため, 省エ ネルギー対策の立案や $\mathrm{CO}_{2}$ 排出量の予測などには, 住宅のエネルギー 消費，取り分け空調用エネルギー消費状況の解明が重要な課題になっ ている。

空調用エネルギー消費量の解析に調查的研究は有効な方法である が, コンピュータシミュレーションによる解析方法も確立されつつある。こ れまでは，建物の熱的シミュレーション用気象データがほとんどないため， 中国での建物の年間空調負荷計算およびその地域特性の検討は困難 であった。空調設備設計用の気象デー夕はあるが, それはあくまでも空 調設備の最大負荷を計算するためのもので, 年間エネルギー消費量の 解析に不向きである。Lin とMatsuo は簡易式によるアジアにおける年間 空調負荷の地域分布について調べている ${ }^{11}$ が, サンプル数が少ないた めか，地形や標高などが暖房負荷に及ぼす影響は反映されていない。 著者らが中国の主要都市における標準年気象データを開発したことによ $\eta^{2)}$ ，建物の年間シミュレーションがはじめて可能になった。 本報は中国の主要都市における標準年気象データを用いて住宅の
シミュレーションを行い, それに基づいて作成した回帰式を用いて暖房 負荷の地域特性を解明しようとするものである。まず, 既報で開発された 手法を用いて, 標準年気象デー夕の対象都市を 25 から 46 にした。次に, 2 種類の集合住宅モデルを想定し，上述した 46 都市での年間暖房負荷 を計算した。さらに, 暖房ディグリーデー, 冬季日積算日射量などの気象 要素および熱損失係数, 日射熱取得係数などの住宅の熱的要素を用い て, 年間暖房負荷を予測するための重回帰式を作成した。最後に, 530 地点の住宅年間暖房負荷を求め, 中国における年間暖房負荷の等値 線図を作成した。

\section{2. 標準年気象データの概要}

著者らは既報 ${ }^{2-て ゙ は, ~} 1982$ 年から 1997 年まで 16 年間の 3 時間間隔の 観測気象デー夕を用いて, 中国における 25 都市の標準年気象デー夕を 開発している。観測気象データの中に日射量が含まれていないため, 多 変量回帰に基づいて日射量の推定式を求めている。また, 乾球温度, 相 対湿度, 日射量および風速の月平均值および累積度数関数に基づいて 平均月を選出した。さらに, 調和分析および多変量回帰を用いて, 3 時間 デー㚈対して補間を施した。本報では, 既報に引き続いて標準年気象 デー夕を作成し，その対象都市を 25 から 46 に拡大した。なお，本報にお

筑波技術短期大学建築工学科 助教授・工博

** 筑波技術短期大学建築工学科 教授.工修

*** 九州大学大学院総合理工学研究科環境工ネルギー工学専攻 厂博

**** 筑波技術短期大学建築工学科 助手. 工修
Assoc. Prof., Dept. of Architectural Eng., Tsukuba College of Tech., Dr. Eng.

Prof., Dept. of Architectural Eng., Tsukuba College of Tech., M. Eng.

Department of Energy and Environmental Engineering, Kyushu University, Dr. Eng.

Research Assoc., Dept. of Architectural Eng., Tsukuba College of Tech., M. Eng. 
表1 標準年気象データの対象都市一覧および各地の月平均気温, 相対湿度

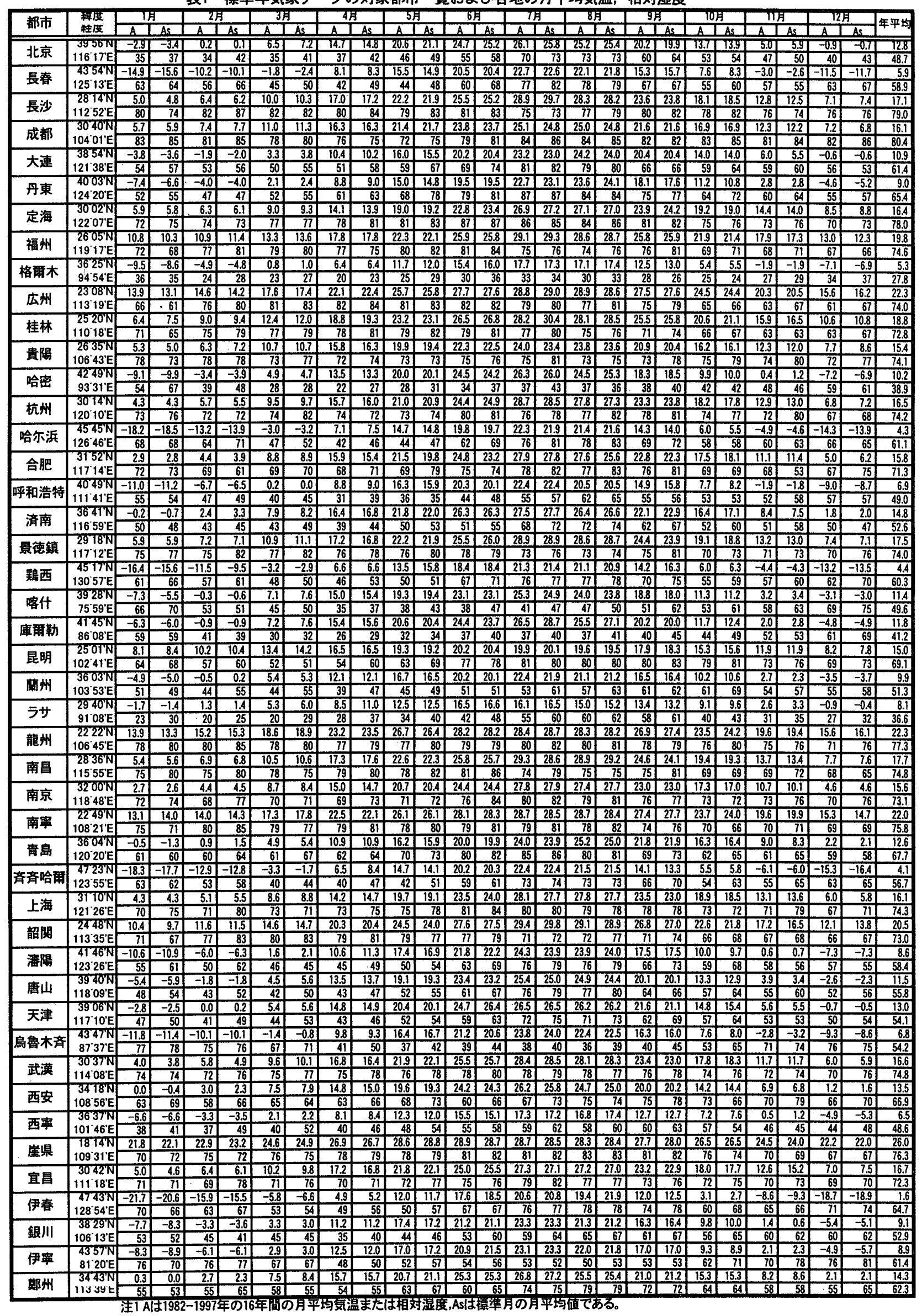

注2 各都市の上段の数字は乾球温度 $\left({ }^{\circ} \mathrm{C}\right)$ ，下段は相対湿度(犺である。 


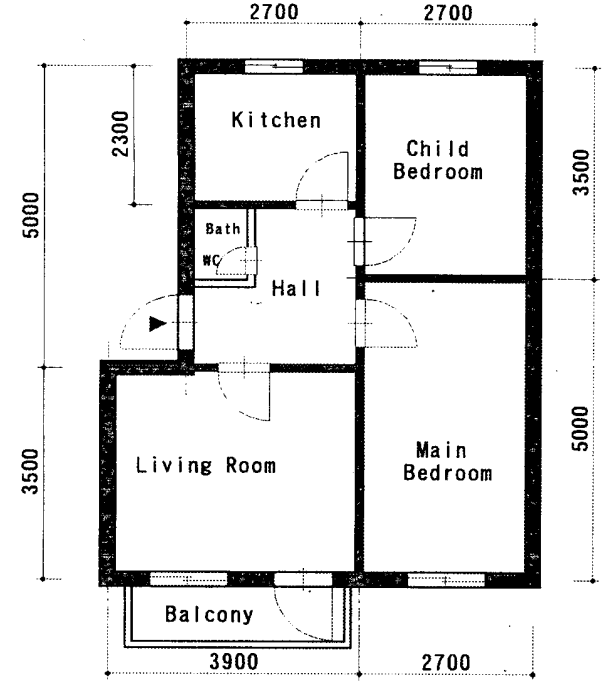

(1) モデルA

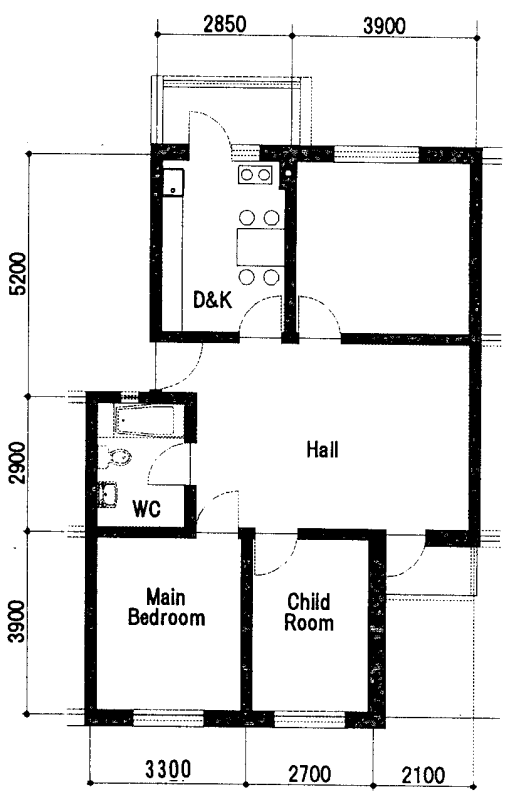

(2) モデルB

図 1 シミュレーション用集合住宅モデ (単位 $\mathrm{mm}$ )
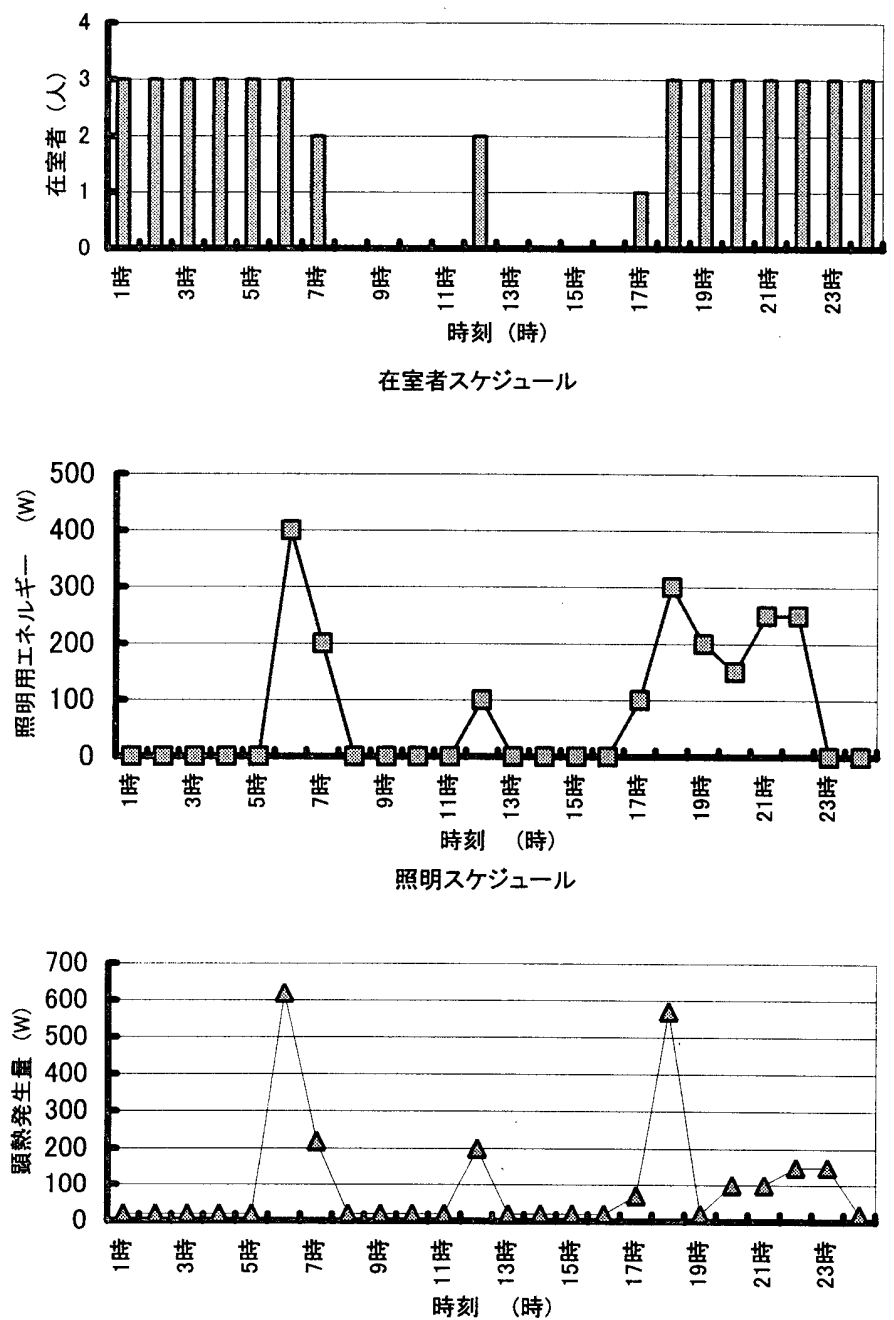

発熱機器スケジュール

図 2 在室者, 照明, 発熱機器のスケジュール
ける標準年気象データの作成方法は基本的に前報の方法を継承してい る。

今まで省市自治区の行政府所在地以外の都市における月平均気温 および相対湿度に関係する資料はほとんどないため,ここで上述した 46 都市の 1982 年〜1997 年の月平均および年平均温度と相対湿度を表 1 に示す。また, 標準月に選ばれている月の平均温湿度も比較のために表 1 に併記している。上段は乾球温度，下段は相対湿度である。また，Aの 列は 16 年間にわたる該当月の乾球温度または相対湿度の月平均值で, As の列の数值は標準月の月平均值である。表 1 からわかるように, 標準 月と 16 年間の月平均值との差は乾球温度では約 $1^{\circ} \mathrm{C}$ 以内, 相対湿度で は約 10\%以内になっている。

3. モデル住宅とシミュレーションの方法

中国の暖房負荷の地域特性を調べるために, 住宅のモデルを想定し, そのシミュレーションを行う。中国都市部の居住形態を考えると, 戸建住 宅は極めて少ないため，集合住宅を想定している。住宅の一般性を考え， 図1に示すように, 2 種類の住戸を設定した。モデル A とモデ B の延べ 床面積はそれぞれ $50.1 \mathrm{~m}^{2}$ と $86.8 \mathrm{~m}^{2}$ となっている。北京市の 2000 年の統 計 ${ }^{3 k}$ によれば, 都市部の住民の平均住宅面積は $16.2 \mathrm{~m}^{2}$ /人となっており, 3 人家族を仮定する場合, 既存の平均住宅規模はモデル A とほほ一致 する。また，現在新築中の集合住宅の 1 住戸述べ床面積は $86 \mathrm{~m}^{2}$ になっ ている4)。したがって, モデル A とモデル B はそれぞれ中国都市部の既 存または新築集合住宅の平均的なものと言えよう。住宅はレンカ造とし, 外壁の厚さは一律 $36 \mathrm{~cm}$ である。また, 内壁の厚さを $24 \mathrm{~cm}$ とする。中国の 実際の住宅構造や,レンガの保温性を考え, 外壁に断熱材を設けないこ とにする。住宅の換気回数はすべて 0.5 回 $/$ と仮定し, 暖房は 24 時間連 続運転かつ全室暖房としている。空は建物の所在地と関係なく2 重ガラス としている。モデル A およびモデル B の熱損失係数 ${ }^{51}$ はそれぞれ $1.36 \mathrm{~W} / \mathrm{m}^{2 \circ} \mathrm{C}$ c $1.13 \mathrm{~W} / \mathrm{m}^{2 \circ} \mathrm{C}$ なっている。シシュレーションの対象となる住 戸は集合住宅の中間階にあり, 同じ階の両端でない住戸を想定している。 
表2 各都市における暖房ディグリーデーHDD20

およびシミュレーションによる暖房負荷

\begin{tabular}{|c|c|c|c|c|c|c|}
\hline \multirow[b]{2}{*}{ 都市 } & \multirow{2}{*}{ 開始日 } & \multirow{2}{*}{ 終了日 } & \multirow{2}{*}{ 暖房日数 } & \multirow{2}{*}{ HDD2O } & \multicolumn{2}{|c|}{ 暖屏負荷 $(\mathrm{MJ} / \mathrm{m} 2)$} \\
\hline & & & & & モデルA & モテルB \\
\hline 北京 & 10月12日 & 4月18日 & 188 & 3101 & 379 & 353 \\
\hline 長春 & 9月16日 & 5月16日 & 243 & 5218 & 674 & 626 \\
\hline 長沙 & 11月7日 & 4月7日 & 152 & 1790 & 206 & 195 \\
\hline 成都 & 10月29日 & 4月7日 & 160 & 1758 & 196 & 188 \\
\hline 大連 & 10月12日 & 5月13日 & 213 & 3429 & 428 & 401 \\
\hline 丹東 & 9月26日 & 5月15日 & 232 & 4096 & 509 & 476 \\
\hline 定海 & 11月9日 & 4月21日 & 162 & 1808 & 204 & 194 \\
\hline 福州 & 11月28日 & 4月3日 & 127 & 988 & 110 & 105 \\
\hline 格尔木 & 9月3日 & 6月14日 & 285 & 5089 & 618 & 569 \\
\hline 広州 & 12月16日 & 3月4日 & 78 & 401 & 46 & .45 \\
\hline 桂林 & 11月24日 & 4月3日 & 131 & 1269 & 140 & 134 \\
\hline 贵陽 & 10月22日 & 4月11日 & 171 & 1841 & 205 & 196 \\
\hline 哈密 & 9月30日 & 4月28日 & 211 & 3959 & 504 & 467 \\
\hline 杭州 & 11月8日 & 4月16日 & 160 & 1894 & 232 & 213 \\
\hline 哈尔浜 & 9月12日 & 5月18日 & 249 & 5724 & 742 & 687 \\
\hline 合肥 & 10月27日 & 4月15日 & 170 & 2198 & 251 & 238 \\
\hline 呼和浩特 & 9月16日 & 5月6日 & 234 & 4749 & 597 & 553 \\
\hline 済南 & 10月16日 & 4月7日 & 174 & 2536 & 316 & 296 \\
\hline 景徳鎮 & 11月8日 & 4月7日 & 150 & 1697 & 195 & 190 \\
\hline 咀西 & 9月11日 & 5月22日 & 254 & 5639 & 721 & 668 \\
\hline 客什 & 10月3日 & 4月14日 & 193 & 3325 & 406 & 376 \\
\hline 庫尔勒 & 10月8日 & 4月14日 & 188 & 3411 & 428 & 399 \\
\hline 昆明 & 10月18日 & 3月24日 & 157 & 1495 & 166 & 155 \\
\hline 闻州 & 9月24日 & 5月15日 & 234 & 3640 & 441 & 414 \\
\hline ラサ & 8月15日 & 5月30日 & 288 & 4025 & 457 & 428 \\
\hline 龍州 & 12月20日 & 3月1日 & 70 & 325 & 42 & 41 \\
\hline 南昌 & 11月8日 & 4月7日 & 151 & 1701 & 194 & 184 \\
\hline 南京 & 10月26日 & 4月17日 & 174 & 2245 & 265 & 251 \\
\hline 南驾 & 12月17日 & 3月4日 & 76 & 470 & 47 & 45 \\
\hline 青島 & 10月17日 & 5月7日 & 202 & 2906 & 355 & 334 \\
\hline 紊彥哈尔 & 9月12日 & 5月16日 & 247 & 5718 & 756 & 701 \\
\hline 上海 & 11月7日 & 4月21日 & 166 & 2005 & 227 & 215 \\
\hline 韶関 & 11月26日 & 3月30日 & 125 & 913 & 106 & 102 \\
\hline 潘陽 & 9月24日 & 5月2日 & 221 & 4320 & 545 & 508 \\
\hline 唐山 & 10月10日 & 4月28日 & 200 & 3501 & 430 & 400 \\
\hline 天津 & 10月17日 & 4月17日 & 182 & 3062 & 372 & 345 \\
\hline 烏魯木斉 & 9月21日 & 5月12日 & 234 & 4883 & 621 & 578 \\
\hline 武漠 & 11月5日 & 4月7日 & 154 & 1917 & 226 & 214 \\
\hline 西安 & 10月12日 & 4月16日 & 186 & 2697 & 322 & 303 \\
\hline 西蜜 & 9月3日 & 6月8日 & 279 & 4634 & 550 & 510 \\
\hline 崖県 & - & - & 0 & 0 & 0 & 0 \\
\hline 宜昌 & 11月6日 & 4月5日 & 151. & 1771 & 221 & 197 \\
\hline 伊春 & 9月8日 & 5月29日 & 264 & 6589 & 852 & 789 \\
\hline 銀川 & 9月24日 & 5月4日 & 223 & 4007 & 506 & 471 \\
\hline 伊窝 & 9月27日 & 4月27日 & 213 & 3996 & 510 & 476 \\
\hline 鄭州 & 10月14日 & 4月14日 & 182 & 2581 & 314 & 294 \\
\hline
\end{tabular}

現在の都市部の家庭構成を考え, 居住者は子供 1 人の 3 人家族と仮定 して, 在室者, 照明および室内発熱器具のスケジュールは図 2 のように想 定している。夫婦は共働きとし，昼間には在室者がいないが，12 時に夫 婦の中の 1 人と子供が帰宅して炊事し，昼食をとる。暖房の設定温度は $20^{\circ} \mathrm{C}$ と，湿度は成り行きである。実際に暖房を行う場合，間欠運転も考 えられるが, 本研究では, 暖房負荷の上限を求めるよう, 連続運転を仮定 した。

前章で述べた中国の標準年気象データを多数室シミュレーションプロ

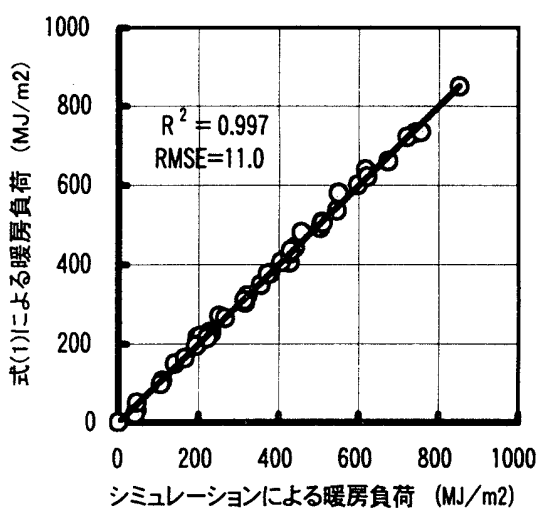

图3 式(1)による暖房負荷とシミュレーションによる 㖕算結果の相関 (モデルA)

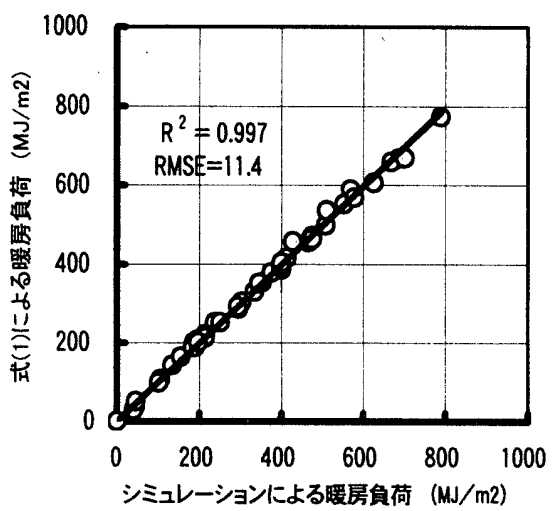

図4 式(1)による暖房負荷とシミュレーションによ る計算蛣果の相関 (モデルB)

グラム PSSP ${ }^{61}$ に入力して年間暖房負荷を計算している。本プログラムのア ルゴリズムの妥当性や計算精度はすでに検証しており，本研究ではそれ について検討を行わない。前述した 46 都市の暖房の開始日, 終了日お よび暖房ディグリーデーは次のように求めている。まず, 1982 年〜1997 年の観測気象デー夕を用いて 365 日の日平均外気温を求め, それが $15^{\circ} \mathrm{C}$ 以下に下がる日を暖房開始日，15ำ以上に上がる日の前日を暖房 終了日とする。本研究では冬季の暖房設定温度を $20^{\circ} \mathrm{C}$ 想定して暖房 ディグリーデーを算出している。しかし，日射熱取得や居住者の人体発 生熱, 照明, 器具発生熱による室温の上昇を考えれば, 日平均外気温が $15{ }^{\circ} \mathrm{C}$ 以下に下がる時期から暖房を始めることは妥当であろう。坊垣らの日 本における調查 ${ }^{7}$ によれば，約 $50 \%$ 住宅では外気温が $10^{\circ} \mathrm{C}$ まで下がる と暖房を始めるという結果を得ているが, 本研究では, 連続運転を行う場 合の全暖房期間の暖房負荷を調べることを目的にしており，以上のように

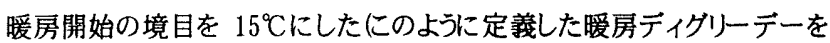
$H D D_{20}$ と表す)。各都市における暖房ディグリーテー $H D D_{20}$ 之暖房開 始日，終了日を表 2 に示す。

\section{4. 中国における暖房負荷の地域特性}

\section{4-1 年間暖房負荷のシミュレーション結果}

第 2 章で述べた中国の 46 都市における標準年気象デー夕をシミュレ ーションプログラムPSSPに入力し，前章で述へた集合住宅モデ A およ

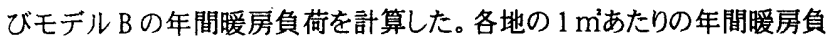
荷を前述した表 2 に示す。46 都市の中で暖房負荷が最も大きい都市は 斉斉哈尔で, 最も小さい都市は海南島の崖県である。また,すべての都 市において，モデル Aの単位面積あたりの暖房負荷はモデル B のそれよ 


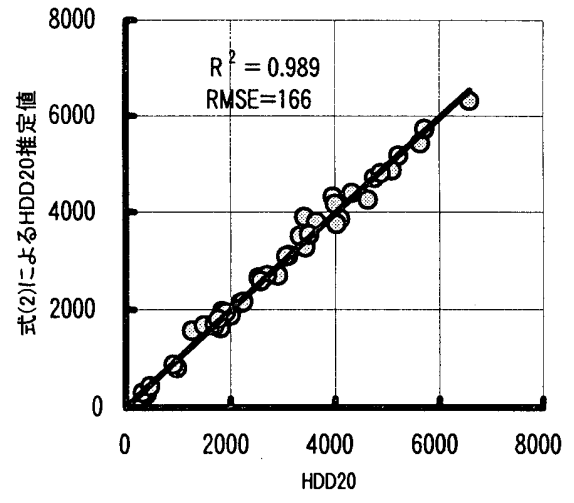

図5 式(2)によるHDD20推定値と真值との比較

り大きくなっている。それは主にモデル A の方が熱損失係数が大きいた めである。

\section{4-2 回帰式による年間暖房負荷解析}

中国の暖房負荷の地域特性について検討するために; 上記の 46 都市 のみでなく, より多くの地点における暖房負荷を知る必要がある。しかし, 現時点では, 他の地点の標準年気象デー夕はまだ開発されていないた め, シミュレーションによる暖房負荷の計算は困難である。そこで, 本研究 では暖房負荷の推定式を作成することを試みた。

暖房負荷の影響因子として, 次のものが考えられる。外部気象条件に おける因子としては外気温と日射量, 建物における因子として熱損失倸 数, 日射熱取得率, 建物の熱容量, 居住者の生活活動による熱発生量 などである。ここで, 外気温と日射量をそれぞれ暖房ディグリーデーと1月 の平均日積算日射量で代表する。本研究では, 暖房の連続運転を仮定 しているため, 建物の熱容量の負荷への影響は小さいものと考えられ無 視している。表 2 に示す年間暖房負荷と上述の影響因子との関係を調べ, 次の回帰式を得た。

$$
\begin{aligned}
L_{H}= & 1.01+1.1696 \cdot Q \cdot 0.00876 \cdot H D D_{20}-0.351 \cdot \mu \cdot I_{D} \cdot H D \\
& -0.227 \cdot\left(H_{B}+H_{E}+H_{L}\right) \cdot H D / S
\end{aligned}
$$

ここで, $L_{H}$ は $1 \mathrm{~m}$ あたりの年間暖房負荷 $\left(\mathrm{MJ} / \mathrm{m}^{2}\right), Q$ は熱損失係数

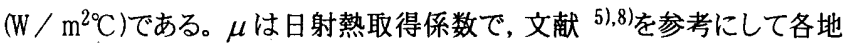
の值を求めている。 $I_{D}$ は 1 月における平均日積算日射量 $\left(\mathrm{MJ} /\right.$ 日 $\left.\cdot \mathrm{m}^{2}\right)$, $H D$ は暖房日数(表 2)である。 $H_{B}$ は人体による顕熱発生量(MJ/日)で, 図 2 に示す在室者スケジュールによる顕熱発生量の日積算值である。な

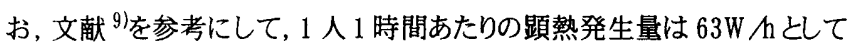
いる。 $H_{E}$ は器具による顕熱発生量(本研究では $8.93 \mathrm{MJ} /$ 日),$H_{L}$ は照 明による顕熱発生量(本研究では 7.02MJ/日), $S$ は延べ床面積 $\left(\mathrm{m}^{2}\right)$ であ る。日射熱取得の項 $\mu \cdot I_{D} \cdot H D$ と室内熱発生項 $\left(H_{B}+H_{E}+H_{L}\right) \cdot H D / S$ が暖芳負荷を減らす方向に働くため, これらの 係数はマイナスになっている。

式(1)による各都市のモデル A およびモデル B における年間暖房負荷 推定值と表 2 に示すシシュレーションによる計算値との相関をそれぞれ図 3 と図 4 に示す。いずれも高い相関係数を示しており, 推定誤差を表す RMSE はそれぞれ $11.0 \mathrm{MJ} / \mathrm{m}^{2}$ と $11.4 \mathrm{MJ} / \mathrm{m}^{2}$ になっている。

式(1)を用いて表 2 以外の地点の暖房負荷を推定する際, 対象となる地 点の暖房ディグリーデー $H D D_{20}$ と暖房日数 $H D$ が必要になってくる。 そこで，任意地点の $H D D_{20}$ と $H D$ を推定するために，既知の 46 都市 のデー夕を用いて次の回帰式を得た。

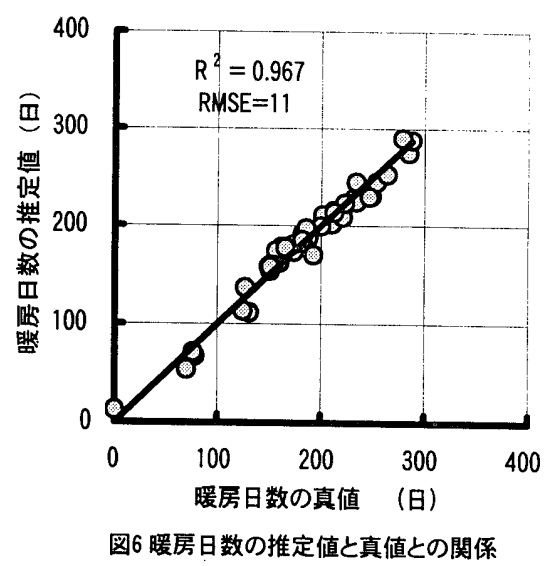

$H D D_{20}=2609.0-168.36 \cdot \theta_{1}+0.2330 \cdot h$

ここで, $\theta_{1}$ は 1 月の月平均気温 $\left({ }^{\circ} \mathrm{C}\right), h$ は標高 $(\mathrm{m})$ である。対象となる 地点の緯度も変数として考えられるが, その偏相関係数が非常に小さい ため,ここで报わないことにした。図 5 は式(2)による $H D D_{20}$ の推定值と前 述した観測デー夕から得た值(真值)との相関であり, 式(2)を用いれば $H D D_{20}$ が精度よく推定できるといえる。

暖房日数 $H D$ は $H D D_{20}$ と正の相関, 室温と外気温との差と負の相関 があると考えられる。また, 表 2 からわかるように, ラサ, 格尔木, 西寧のよ うな標高が $2000 \mathrm{~m}$ 以上の地点では他の地域と比べ, 同等の $H D D_{20}$ でも $H D$ が大きい傾向にある。したがって, 暖房日数 $H D$ を推定する際, $H D D_{20}$ と室内外温度差のほかに，標高も変数として加えた。このように して作成した推定式は次のとおりである。

$H D=7.593+0.5712 \cdot \frac{H D D_{20}}{20-\theta_{1}}+0.006111 \cdot\left(\frac{H D D_{20}}{20-\theta_{1}}\right)^{2}-0.00355 \cdot h$

図6からわかるように，暖房日数 HD は式(3)でRM SE=11 日で推定でき る。

なお，1月の平均日積算日射量 $I_{D}$ は NASA (National Aeronautics and Space Administration)が公開している世界各地の月平均日積算日射量 を使用している 10$) 。$

\section{4-3 年間暖房負荷等値線図}

中国の年間暖房負荷の地域特性を調べるために，中国の 530 地点の 暖房負荷を式(1)を用いて推定し，各地点におけるモデル Aとモデル B の 年間暖房負荷を計算し，その平均値を求めた。第 3 章で述べたように，モ デル A とモデル B はそれぞれ既存と新築住宅の床面積の平均に近いも ので, しかも, 両モデルの年間暖房負荷の相違は僅かであるため,これら の平均值で現段階における中国の住宅暖房負荷レベルを代表させること にした。各地点の標高および 1 月の月平均気温は文献 11)の地形図およ び気候図から読み取っている。図 7 はその平均值による $1 \mathrm{~m}^{2}$ たり年間暖 房負荷の等值線図である。暖房設定室温が $20^{\circ} \mathrm{C}$ 場合, 中国全土にお ける暖房負荷は $0 \sim 1100 \mathrm{M} \mathrm{J} / \mathrm{m}^{2}$ の範囲にある。最南端の海南島では, 年 間を通じて暖房負荷がゼロに近く, 暖房設備は不要である。経度 $105^{\circ} \mathrm{E}$ 以東では, 暖房負荷が緯度の增大につれて增えていく。しかし, 経度 $105^{\circ} \mathrm{E}$ 以西では, 緯度のみで年間暖房負荷の大小は説明できない。標 高が $4000 \mathrm{~m}$ 以上(文献 111 による)の藏北高原を中心とした年間負荷が $900 \mathrm{MJ} / \mathrm{m}^{2}$ 以上の地域があり，その北側に年間暖房負荷が $500 \mathrm{MJ} / \mathrm{m}^{2}$ 以 下の塔里木盆地が存在する。このように, 年間暖房負荷は緯度だけでな く，標高の影響も大きく受ける。また, 祁連山・巴音山や巴顔喀拉山, 鄂 


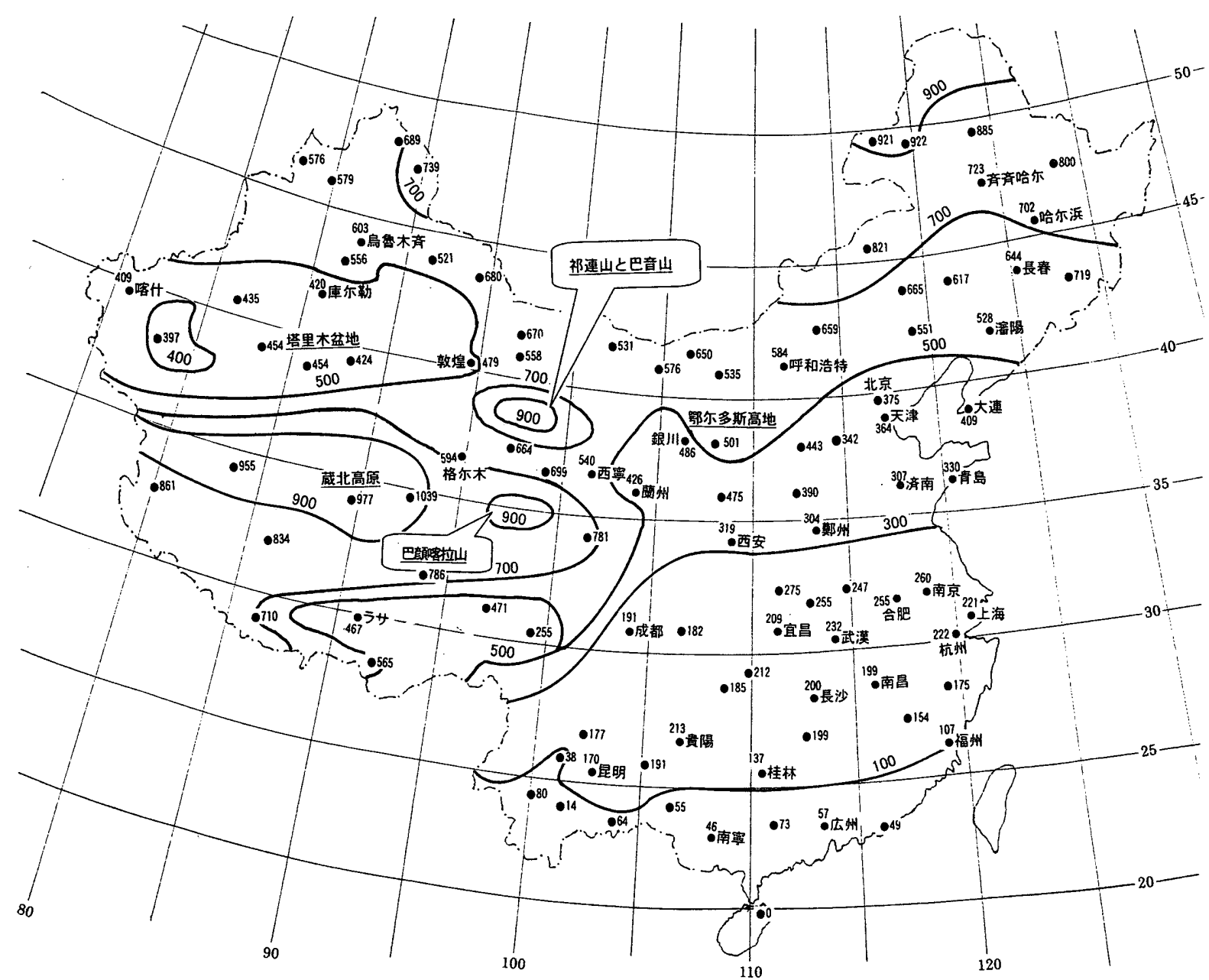

図 7 年間暖房負荷の等値線図(図中の数値は年間暖房負荷 $\mathrm{MJ} / \mathrm{m}^{2}$ )

尔多斯高地による局所的に年間負荷の増大している個所も点在している ことが見受けられる。

\section{5. 終わりに}

本論文では, 既報に引き続き中国の主要都市における標準年気象テ 一夕を開発し，それを用いて住宅のシミュレーションを行い，46 都市にお ける住宅の年間暖房負荷を計算した。また，暖房ディグリーデーなどの 説明変数による年間暖房負荷を予測するための重回帰式を作成し, 住 宅の年間暖房負荷の地域特性を解明した。本論文で得られた知見をま とめると次のとおりである。

(ア) 中国の標準年気象データの対象都市を 25 から 46 に拡大した。

（イ） 2 種類の集合住宅モデルを想定し,それに基づいて年間暖房 負荷の推定式を作成した。その推定值はシミュレーションによる 結果とよく一致している。

(ウ）想定した住宅の年間暖房負荷の等值線図を作成した。

（工） $105^{\circ} \mathrm{E}$ の以東では，住宅の年間暖房負荷に対して緯度が主な

影響要素であるが, その以西では標高も大きく影響している。 今後は住宅の冷房負荷の地域特性を解明する予定である。

\section{謝 辞}

本研究の遂行にあたり,カリフォルニア大学 Lawrence Berkeley National Laboratory の Joe Huang 氏にソースデータの提供と研究の助
言をしていただいた。また，テー夕処理に筑波技術短期大学卒論生の山 根名保子と渡邆和人両君の協力を得た。ここに記して感謝致します。

\section{参考文献}

1) Lin and Matsuo: A Simplified Seasonal Heat Load Index and Its Application to Evaluation of a Building Shelter's Design Condition on a Global Scale, Part 2 Annual Heat Load Distribution Maps in Asia, 空気調和・得生工学会猃文集 No. 27, pp. 51-59, 1984

2）張 晴原, 浅野賢二: 中国主要都市の標準年気象デー㚈関する研究，日本 建筑学会計画系論文集, No.543, pp.65-70, 2001 年 5 月

3）中国国際広播電台ホームページ: http://www.crinews.com/

4) 節能住宅設計実例図集編集委員会: 節能住宅設計実例図集，中国建築工業 出版社, p.9, 1999 年

5）住宅・建築省エネルギー機桠 住宅の新省エネルギー基準, p.21，平成 4 年版

6) T.Hayashi, et al.: Prediction of Air Distribution in Multiroom Buildings, Proceedings of Roomvent'87, pp.1-20, 1987

7）坊垣和明 他：全国的調查に基づく住宅の冷暖房時間および冷暧房期間に関 する研究, 日本建築学会計画系論文集, No.509, pp.41-47, 1998 年 6 月

8）住宅·建築省エネルギー機構:新版拡张ディグリーデー表, 昭和 58 年

9) 宇田川光弘: パソコンによる空気調和計算法, オーム社, p.174 昭和 61 年

10) Atmospheric Sciences Data C enter ホームページ http://eosweb. larc. nasa. gov/(2001 年 1 月現在)

11）中国地図出版社：中国綜合地図集，pp.9·10,1990 年 